This item was submitted to Loughborough's Research Repository by the author.

Items in Figshare are protected by copyright, with all rights reserved, unless otherwise indicated.

\title{
Boron mass transfer during seeded microfiltration.
}

PLEASE CITE THE PUBLISHED VERSION

http://www.sciencedirect.com/science/article/pii/S0263876206728581

\section{PUBLISHER}

Elsevier $\odot$ Institution of Chemical Engineers

VERSION

AM (Accepted Manuscript)

LICENCE

CC BY-NC-ND 4.0

\section{REPOSITORY RECORD}

Holdich, R.G., lain W. Cumming, and Stefano Perni. 2012. "Boron Mass Transfer During Seeded Microfiltration.”. figshare. https://hdl.handle.net/2134/9309. 
This item was submitted to Loughborough's Institutional Repository (https://dspace.lboro.ac.uk/) by the author and is made available under the following Creative Commons Licence conditions.

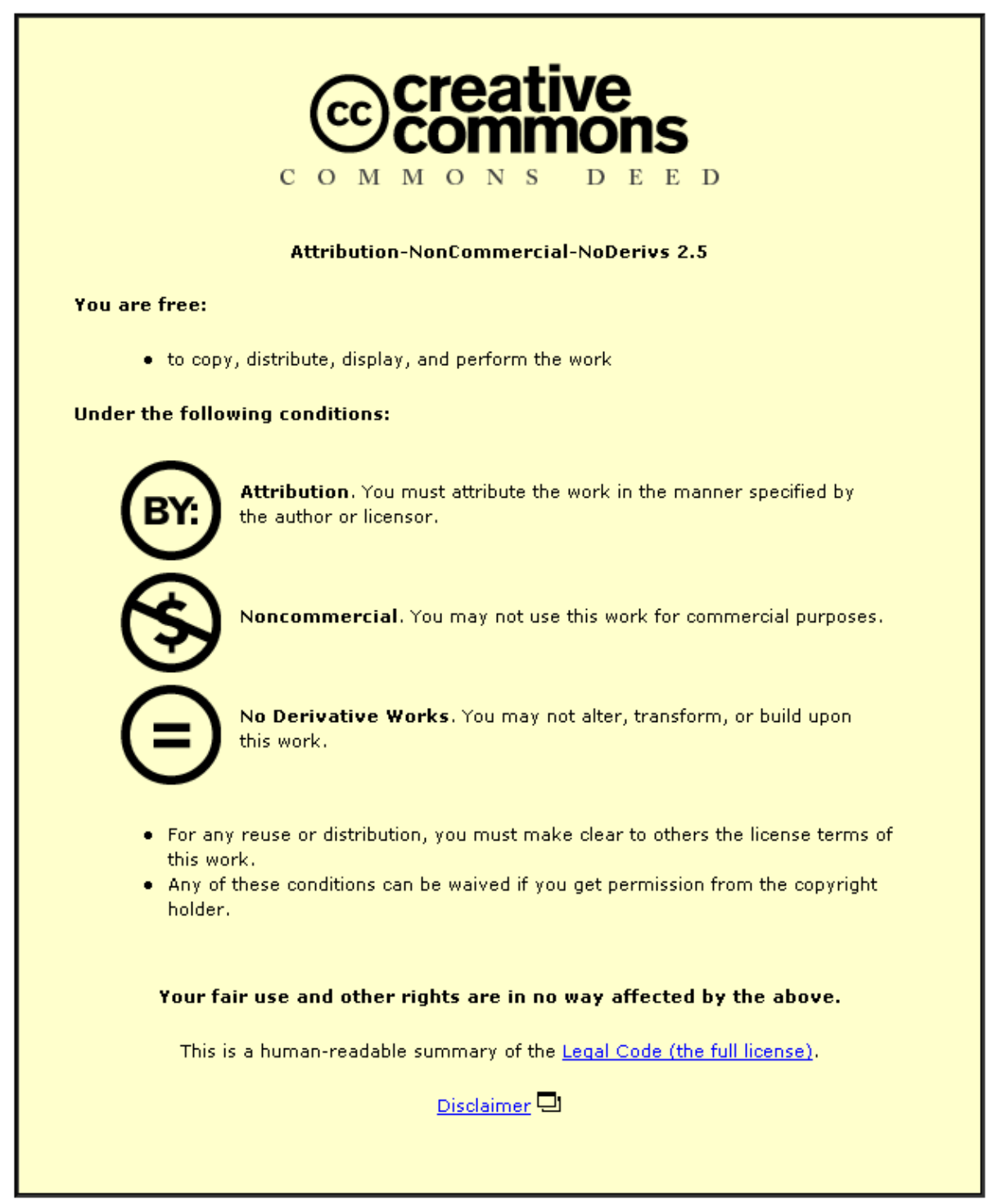

For the full text of this licence, please go to: http://creativecommons.org/licenses/by-nc-nd/2.5/ 


\section{Boron Mass Transfer During Seeded Microfiltration \\ R.G. Holdich, I.W. Cumming and S. Perni \\ Department of Chemical Engineering, Loughborough University, Leicestershire, LE11 3TU, U.K.}

abstract

Seeded microfiltration combines the processes of microfiltration and sorption of a solute onto a solid particle, including ion exchange. The process can be performed for investigations in simple stirred cells, for laboratory mass transfer analysis, and for process-scale applications in crossflow filtration systems. Seeded microfiltration of boron at feed concentrations of up to $4 \mathrm{ppm}$ using a N-glucamine type ion exchange resin showed that the process was dependent on the internal diffusion of boron inside the resin particle, with an effective particle diffusivity of $5.5 \times 10^{-10} \mathrm{~m}^{2} \mathrm{~s}^{-1}$. The kinetics of the process were modelled by a coupled mass transfer model, based on a well mixed stirred system, aqueous film diffusion, particle diffusion and a Langmuir type isotherm for the equilibrium conditions. The modelling suggests that a resin particle diameter of 50 micrometers would provide improved boron extraction performance, whilst easily being retained within the microfiltration process. A comparison of the analysis of mass transfer between a conventional batch stirred cell and the continuously fed seeded microfiltration system shows that the continuously fed system has many advantages for the laboratory investigation of mass transfer parameters.

keywords

ion exchange, membrane, sorption, diffusion 


\section{INTRODUCTION}

Boron is a common constituent in nature, often found in the form of hydrates of alkali and alkaline earth metals as borates and borosilicates. Boron in water, under near neutral $\mathrm{pH}$ conditions, is usually found as the dissociated form of boric acid - which forms the hydroborate ion:

$$
\mathrm{B}(\mathrm{OH})_{3}+2 \mathrm{H}_{2} \mathrm{O} \leftrightarrow\left[\mathrm{B}(\mathrm{OH})_{4}\right]^{-}+\mathrm{H}_{3} \mathrm{O}^{+}
$$

In general, two boric acid types exist in the free state, metaboric $\mathrm{HBO}_{2}$ and orthoboric $\mathrm{B}(\mathrm{OH})_{3}$. In solution, metaboric acid converts rapidly to orthoboric acid due to hydration. Othoboric acid dissociates weakly $\left(\mathrm{k}_{1}=7.3 \times 10^{-10}\right)$ to form monoborates and some polyborates, depending on temperature, $\mathrm{pH}$ and concentration. At low concentration $\mathrm{B}(\mathrm{OH})_{4}{ }^{-}$is the only significant species in solution, while at higher concentration polyborates: tri-, tetra-, and penta- may exist.

Boric acid can be derived from weathered rocks or volcanic activity. It is a necessary trace nutrient for plants and animals. In industry, boron compounds are widely employed, for example: in medicine for the preparation of disinfectants and drugs; in neutron-absorbing materials, e.g. for control rods and neutron shields; in the treatment of brain tumours; in the glass industry for the production of optically and chemically stable glass; as a compound of enamels to increase hardness; to protect metal against oxidation during soldering; as an additive to electrolytes in nickel plating; in the cosmetic, leather, textile, rubber and paint industries as a preservative and as a fire retardant. Its uses as a preservative and fire retardant are increasing and, as a result, it is found in increasing concentrations in rivers and other surface waters which are used as a supply of drinking water (Simonnot et al, 2000). The World Health Organisation has set a maximum recommended level of boron of $300 \mathrm{ppb}$ in drinking water (WHO, 
1998) and conventional water treatment technology is not very effective at removing boron (Dilek et al, 2002). Even low-pressure reverse osmosis membranes, developed for potable water production from surface waters, have only limited boron removal capability (Nadav, 1999). Thus, chelating ion exchange resins have been developed for the removal of boron from water (Kabay, 2004).

It is common for the boron specific ion exchange resins to be supplied in the chloride form, but in most industrial processes the hydroxide form of the resin is preferred. Hence, an anion swap stage is normally employed, washing with caustic solution followed by water rinsing. The resulting ion exchange resin reaction, used for the extraction of boron, can be written as

$$
\mathrm{R}^{+} \mathrm{OH}^{-}+\left[\mathrm{B}(\mathrm{OH})_{4}\right]^{-} \leftrightarrow \mathrm{R}^{+}\left[\mathrm{B}(\mathrm{OH})_{4}\right]^{-}+\mathrm{OH}^{-}
$$

where $\mathrm{R}$ represents the polymer bead chelating ion exchange resin. The equilibrium appears to be a function of $\mathrm{pH}$, but in practice the extraction is reasonably independent of $\mathrm{pH}$ above 3; falling off rapidly at lower $\mathrm{pH}$ values to zero extraction at $\mathrm{pH}$ of 1 (Badruk et al, 1999a). Hence, regeneration of the boron loaded resin is possible by an acid wash, followed by further resin conditioning.

A key factor in the efficient use of ion exchange is the capacity for boron by the ion exchange resin. Boron sorption capacity on anion exchange resins varies with temperature, concentration and crosslinkage of the polymer matrix. A semi-empirical correlation has been presented (Lou et. al., 1999) to account for these variations based on boron chemistry and changes in Gibb's free energy. The greatest boron capacity appeared to be $30 \mathrm{mg}$ boron per gram of resin as a dry mass. However, there are many other factors to consider in the selection of the most appropriate resin for an 
application, such as: availability, ability to be recycled, resistance to breakage, kinetics of the extraction and cost. Thus, there are a number of ion exchange resins for boron removal, see Table 1, and work to improve the sorption capacity of resins by impregnation with citric and tartaric acids has been presented (Ristić. and Rajaković, 1996). There have been several studies for the removal of boron from geothermal power plant feed water (Badruk et. al.,1999b) and for water purification (Boncukcuoğlu et al. 2004; Dilek et al. 2002).

It appears that the most effective resins for the removal of boron are the N-glucaminetype resins, such as Diaion CRB 02 and Purolite S-108, and it often found that the sorption of both these resins obey the Langmuir isotherm model (Badruk et. al.,1999a; Qi et al, 2002)

$$
q=\frac{q_{\max } b C_{e q}}{1+b C_{e q}}
$$

where $q$ is the concentration of the species on the particles, $C_{\mathrm{eq}}$ is the concentration in the liquid phase in equilibrium with it, $q_{\max }$ is the maximum capacity of the particle and $b$ is a model parameter. The last two parameters are found by experiment.

In the previously mentioned work, where the kinetics of the extraction have been considered, most authors suggest that the process is controlled by diffusion within the resin particle (Badruk et. al.,1999a) rather than through the aqueous film surrounding the particle, or a chemical reaction. However, there is some evidence for first order reaction with respect to the boron (Şahin, 2002), which could imply aqueous film control and evidence for a heterogeneous fluid-solid reaction model based on a pseudo-second order reaction (Boncukcuoğlu, et al, 2004). 
When modelling diffusion within the particle it is possible to consider different diffusivities, such as: the diffusion within the macropores of the resin and the surface diffusion within the resin (Yiacoumi and Tien, 1995; Qi et al, 2002). However, it is not easy to separate the effects of the different internal particle diffusional resistances and for all practical purposes an average, or effective, diffusivity can be defined to account for the mass transfer resistance within the particle. Provided this average diffusion coefficient remains constant, with respect to operating conditions, this enables a predictive study (i.e. design calculations) of the effects of process conditions on the overall process kinetics.

There are several methods that may be applied to the establishment of the necessary parameters for the design calculations: primarily a mass transfer coefficient within the aqueous phase and the effective diffusivity within the particle, when chemical reaction is rapid and can be discounted. In some cases the mass transfer coefficient can be established independently by relating the local hydrodynamics around a particle to the mass transfer coefficient, but the diffusion coefficient within the particle usually requires experimental studies. However, a poorly determined mass transfer coefficient will adversely influence the experimental determination of the effective diffusivity within the particle. Aqueous film diffusion is dependent on the concentration gradient from the bulk solution to the particle surface - so it is best to ensure experimental conditions that ensure that this gradient can be correctly established. This is more likely to be valid when using a low concentration of the transferring species, rather than a high concentration within the bulk - as a significant surface concentration may build up on the particle. The seeded microfiltration system 
provides these optimum mass transfer conditions, making it an ideal system for laboratory studies.

Process scale seeded microfiltration processes also exists (Cumming and Turner, 1989). The main advantage of such systems is that the mass transfer is much faster than packed bed ion exchange, or adsorption, systems as smaller particles are used reducing the limitation of slow mass transfer kinetics within the particle. In seeded microfiltration processes intimate mixing of the particles and solution is provided. The most effective systems have high permeate flux through the membrane used to retain the ion exchange, or adsorption, resin. Under these conditions only a small amount of membrane is required, leading to compact equipment in which the design is provided by the mass transfer kinetics of the process, rather than the hydraulic considerations of the microfilter. Recently, a new design of microfilter has become available for high permeate fluxes and which is ideally suited to use in both laboratory seeded microfiltration investigations and for industrial scale applications (Bromley et al, 2002).

\section{Kinetic modelling}

The following analysis follows a conventional model based on mass transfer resistance within the aqueous film surrounding the particles together with diffusional resistance within the particle. However, the analysis is modified for the continuous nature of the seeded microfiltration process. For a well mixed system, a mass balance on the boron provides

$$
V \frac{\mathrm{d} C}{\mathrm{~d} t}=F\left(C_{\text {feed }}-C\right)-m \frac{\mathrm{d} \bar{q}}{\mathrm{~d} t}
$$


where $V$ is the liquid volume in the cell (see Figure 1), $C$ is the concentration in the solution (both in the cell and at the exit), $C_{\text {feed }}$ is the concentration in the feed to the cell, $F$ is the feed flow rate, $m$ is the mass of resin in the cell and $\bar{q}$ is the average mass of boron per mass of resin. The average mass of boron per mass of resin is obtained by integrating the local mass throughout the resin from $r=0$ to $r=R$

$$
\bar{q}(t)=\frac{3}{R^{3}} \int_{0}^{R} q(r, t) r^{2} \mathrm{~d} r
$$

where $R$ is the bead radius and the diffusion equation for mass transfer inside a particle is

$$
\frac{\partial q}{\partial t}=\frac{1}{r^{2}} \frac{\partial}{\partial r}\left(D_{e f f} r^{2} \frac{\partial q}{\partial r}\right)
$$

where $r$ is a radial position inside the particle and $D_{\text {eff }}$ is the effective diffusion coefficient of boron inside the particle. The mass rate of boron entering the resin is

$$
m \frac{\mathrm{d} \bar{q}}{\mathrm{~d} t}=k A\left(C-C^{*}\right)
$$

where $A$ is the surface area of the resin bead, $C^{*}$ is the equilibrium concentration of boron at the surface of the resin and $k$ is the mass transfer coefficient in the liquid phase. According to film theory

$$
\delta=\frac{D_{\text {liq }}}{k}
$$

where $D_{\text {liq }}$ is the diffusion coefficient of the boron in the bulk liquid phase and $\delta$ is the film thickness (distance over which the liquid phase diffusion takes place). The Frössling equation may be used to evaluate $k$, using the Sherwood, Particle Reynolds and Schmidt numbers

$$
\mathrm{Sh}=2+0.6 \operatorname{Re}_{\text {slip }}{ }^{0.5} \mathrm{Sc}^{0.33}
$$

where 


$$
\mathrm{Sh}=\frac{k 2 R}{D_{\text {liq }}} \quad \mathrm{Sc}=\frac{\mu}{D_{\text {liq }} \rho} \quad \operatorname{Re}_{\text {slip }}=\frac{v_{\text {slip }} 2 R \rho}{\mu}
$$

where $\mu$ is the liquid viscosity and $\rho$ is the liquid density. Under certain circumstances, the terminal velocity of the particle may be calculated by Stokes' law

$$
v_{\text {slip }}=\frac{g(2 R)^{2}\left(\rho_{s}-\rho\right)}{18 \mu}
$$

This correlation is valid for Particle Reynolds numbers less than 0.2, but may be used at higher values with some degree of caution. For values of Particle Reynolds numbers much greater than 0.2 various other correlations, tables, etc. can be used (Holdich 2002). Thus, equation (7) can be used for the mass transfer coefficient by substitution of the Sherwood number and some rearrangement. The equilibrium concentration of boron at the surface of the resin is given by the rearranged form of the isotherm

$$
C^{*}=\frac{\left.q\right|_{r=R}}{b\left(q_{m}-\left.q\right|_{r=R}\right)}
$$

assuming that the anion exchange resin is a spherical particle, and using specific surface area of a sphere, the surface area follows from

$$
\rho_{s}=\frac{m}{V_{\text {resin }}}=\frac{6 m}{A x} \Rightarrow A=\frac{6 m}{\rho_{s} x}
$$

where $V_{\text {resin }}$ is the resin particle volume, $\rho_{s}$ is the density of the particle, $A$ is the surface area and $x$ is the diameter of the resin particle, or bead. Considering the boron flux inside the resin 


$$
\begin{gathered}
k A\left(C-C^{*}\right)=m \frac{\mathrm{d} \bar{q}}{\mathrm{~d} t}=\left.A \rho_{s} D_{\text {eff }} \frac{\partial q}{\partial r}\right|_{r=R} \Rightarrow \\
\frac{\mathrm{d} \bar{q}}{\mathrm{~d} t}=\left.\frac{A}{m} \rho_{s} D_{\text {eff }} \frac{\partial q}{\partial r}\right|_{r=R}=\left.\frac{4 \pi R^{2}}{\rho_{s} 4 \pi R^{3} / 3} \rho_{s} D_{\text {eff }} \frac{\partial q}{\partial r}\right|_{r=R}=\left.\frac{3}{R} D_{\text {eff }} \frac{\partial q}{\partial r}\right|_{r=R} \Rightarrow \\
m \frac{\mathrm{d} \bar{q}}{\mathrm{~d} t}=\left.\frac{3}{R} D_{\text {eff }} m \frac{\partial q}{\partial r}\right|_{r=R}
\end{gathered}
$$

The mass balance for the boron is therefore

$$
V \frac{\mathrm{d} C}{\mathrm{~d} t}=F\left(C_{\text {feed }}-C\right)-\left.\frac{3}{R} m D_{\text {eff }} \frac{\partial q}{\partial r}\right|_{r=R}
$$

Initial conditions for the continuous extraction of boron onto resin in the cell are a user defined process variable, but conventionally the cell contains fresh liquid with no boron, thus

$q(t=0,0 \leq r \leq R)=0$

$C(t=0)=0$

The boundary condition at the centre of the bead $(r=0)$ is

$$
\left.\frac{\partial q(t \geq 0)}{\partial r}\right|_{r=0}=0
$$

The boundary condition at the full radius of the bead $(r=R)$ can be determined as follows

$$
\begin{aligned}
& \left.\frac{3}{R} D_{\text {eff }} m \frac{\partial q}{\partial r}\right|_{r=R}=k A\left(C-C^{*}\right) \Rightarrow \\
& \left.\frac{\partial q}{\partial r}\right|_{r=R}=\frac{k A\left(C-C^{*}\right) R}{3 D_{\text {eff }} m}=\frac{k 4 \pi R^{2}\left(C-C^{*}\right) R}{3 D_{\text {eff }} \rho_{s} 4 / 3 \pi R^{3}}
\end{aligned}
$$

Therefore,

$$
\left.\frac{\partial q(t \geq 0)}{\partial r}\right|_{r=R}=\frac{k}{D_{\text {eff }} \rho_{s}}\left(C-C^{*}\right)
$$

The system of equations that must be solved simultaneously is 


$$
\left\{\begin{array}{l}
V \frac{\mathrm{d} C}{\mathrm{~d} t}=F\left(C_{\text {feed }}-C\right)-\left.\frac{3}{R} m D_{\text {eff }} \frac{\partial q}{\partial r}\right|_{r=R} \\
\frac{\partial q}{\partial t}=\frac{1}{r^{2}} \frac{\partial}{\partial r}\left(D_{\text {eff }} r^{2} \frac{\partial q}{\partial r}\right) \\
q(t=0,0 \leq r \leq R)=0 \\
C(t=0)=0 \\
C^{*}=\left.\frac{q\left(q_{m}-\left.q\right|_{r=R}\right)}{b(t \geq 0)}\right|_{r=0}=0 \\
\left.\frac{\partial q(t \geq 0)}{\partial r}\right|_{r=R}=\frac{k}{D_{\text {eff }} \rho_{s}}\left(C-C^{*}\right)
\end{array}\right.
$$

which can be solved in an equation solver capable of solving ordinary and partial differential equations. The solver used in this work was PDESOL (Numerica, Dallas, USA), and solutions typically took 7 seconds running on a Pentium 4 processor, 2.4 GHz, with 256 MB of RAM.

\section{EXPERIMENTAL}

The physical properties of the Purolite S-108 resin used in this work are reported in Table 2. The resin was initially put into the hydroxide form by washing 8 gram aliquots with $50 \mathrm{ml}$ of $1 \mathrm{M}$ sodium hydroxide solution for 10 minutes, followed by washing with $50 \mathrm{ml}$ aliquots of water until the $\mathrm{pH}$ was less than 8 . Standard boron samples (at $0,1,2,3,4 \mathrm{ppm}$ ) were prepared using a boron standard solution for atomic absorption, diluted from the stock solution at $1000 \mathrm{ppm}$. For boron analysis a UV/visible light spectrometer was used (Shimadzu 1201) at a wavelength of $415 \mathrm{~nm}$. 
The method used for sample preparation is known as the azomethine- $\mathrm{H}$ technique (Global Environmental Monitoring System, United Nations, Ontario, Canada) and is summarised as follows. Azomethine-H solution was prepared by dissolving $0.5 \pm 0.05$ $\mathrm{g}$ of azomethine- $\mathrm{H}$ and $1 \pm 0.05 \mathrm{~g}$ of ascorbic acid in $50 \mathrm{ml}$ of water, which was immediately transferred to a plastic bottle. This solution was made up each day that analysis was required. A buffer solution of $50 \pm 1 \mathrm{~g}$ of ammonium acetate in $100 \mathrm{ml}$ of water, $25 \mathrm{ml}$ of glacial acetic acid and $1.4 \pm 0.06 \mathrm{~g}$ of EDTA di-sodium salt was also prepared. For the analysis, $10 \mathrm{ml}$ of sample water was mixed with $2.5 \mathrm{ml}$ of buffer solution and $2.5 \mathrm{ml}$ of azomethine- $\mathrm{H}$ solution and kept in the dark at room temperature for one hour. After this time, the colour had developed and analysis of the absorbance in a cell of $10 \mathrm{~mm}$ path-length was performed, and the result compared to the calibration line. All analytical chemicals were obtained from Fisher Scientific, Loughborough UK. The Purolite S-108 boron specific ion exchange resin was obtained from Purolite Ltd, Pontyclun, UK.

Two types of extraction using the ion exchange resin were performed: batch extractions in which $0.4 \mathrm{~g}$ of resin (dry mass) was added to $400 \mathrm{ml}$ of water containing boron at a concentration of $4 \mathrm{ppm}$ and stirred. Samples were withdrawn periodically for boron analysis to enable the monitoring of the kinetics. In the second experimental scheme a Micropore Technologies Seeded Microfiltration Cell was used. In all the experiments a buffer ionic strength of $0.01 \mathrm{M}$ was maintained by adding sodium chloride. This ionic strength was selected because it was close to the ionic strength of a local river. Also, a constant ionic strength provided by the background concentration of dissolved material that is inert to the ion exchange, would ensure that the activity coefficients would remain constant. Hence, it is 
possible to work in terms of solution concentration rather than activities and that the possibility of variations in activity being measured as kinetic changes was overcome.

For batch extractions a magnetic stirrer and $\mathrm{pH}$-meter were used, with the solution stirred in a beaker. This represents the conventional approach to mass transfer analysis: starting with a relatively high concentration of transferring species and measuring the reduction in concentration with time. If the mass transfer resistance within the particle is negligible, then it is possible to determine the mass transfer coefficient from a log-linear plot of normalised concentration with respect to time.

For the seeded microfiltrations, illustrated in Figure 1, a cell volume of $400 \mathrm{ml}$ was used with a cell inner diameter of $80 \mathrm{~mm}$. At the base of the cell was a low-pressure drop slotted pore membrane, with a pore width of 8 micrometers. This was of sufficient fineness to retain the resin particles. The total filtration area was $5.03 \times 10^{-3}$ $\mathrm{m}^{2}$. A sealing ring rested between the top of the membrane and the base of the microfiltration cell. Fresh boron containing solution flowed into the cell (Influent) at the same rate as permeate was withdrawn from the cell (Effluent). A peristaltic pump was used to induce the flow. The procedure for each extraction is as follows. Boron solution at a predetermined concentration was prepared and the ionic strength was adjusted to $0.01 \mathrm{M}$ by addition of sodium chloride. The cell was filled with a solution of $0.01 \mathrm{M}$ sodium chloride and $0.4 \mathrm{~g}$ of resin. The tube from the feed tank was filled with the boron solution before connecting to the cell and the speed of the pump was adjusted to provide a flowrate of up to $1000 \mathrm{l} \mathrm{m}^{-2}$ (of membrane area) $\mathrm{h}^{-1}$. A volumetric flow rate of 40 to $70 \mathrm{ml} \mathrm{min}^{-1}$ was employed. The permeate flowrate was monitored by a balance placed under the permeate collecting tank. At predetermined 
times $10 \mathrm{ml}$ of permeate were analysed for boron concentration using the analytical procedure described earlier.

In both sets of tests the $\mathrm{pH}$ was monitored by a $\mathrm{pH}$-meter: Mettler Toledo 320. The main advantage of the seeded microfiltration experimental approach is that it is possible to start off the experiment with a vessel with zero concentration of transferring species (boron) and to monitor the mass transfer in the well mixed system as a function of time. Clearly, in the absence of ion exchange resin the concentration of boron in the permeate from the cell will be equal to that predicted by a conventional stirred tank model of the system. However, with ion exchange, or adsorption, present the outlet concentration will be below that of the conventional stirred tank model. Starting with a zero concentration of the transferring species means that the mass transfer modelling is very sensitive to the value of mass transfer, and particle diffusion, coefficients. Thus, it is possible to determine these values with an improved degree of precision compared to the conventional approach, which is based on batch extraction from a system initially containing a high concentration of the transferring species. It is not possible to start off with a zero concentration of transferring species in a batch system, whilst maintaining a constant volume within the system. Furthermore, the data obtained from a stirred seeded microfiltration cell is scaleable to seeded microfiltration using a crossflow filtration system, which also behaves as a well mixed system. Thus, the simple stirred cell provides a very efficient method for determining both the mass transfer parameters and the hydraulic ones required for a scaled-up system.

For the isotherm analysis, shake-flasks were used. A solution volume of $100 \mathrm{ml}$, of various initial boron concentrations, was added to a $250 \mathrm{ml}$ flask together with $0.1 \mathrm{~g}$ 
of resin and left shaking until there was no further change in the boron concentration in the solution. The initial tests for equilibrium conditions were not performed until after one week of shaking. For the later kinetic tests, ion exchange resin with a smaller particle size was used. This was obtained by crushing the resin in a pestle and mortar. The crushed beads were allowed to settle in a column of water and the very fine solids were removed from the sediment by repeated stirring, settling and decanting. This resulted in a reasonably closely sized finer ion exchange resin, as shown in Table 3 - together with the original resin size distribution.

\section{RESULTS}

The shake flask tests provided data for the isotherm illustrated in Figure 2, together with a fitted Langmuir model with values of $q_{\max }$ of $9.73 \mathrm{mg}$ of boron per g of dried resin, and $b$ of $2.2 \mathrm{~m}^{3} / \mathrm{g}$ of boron. Hence, it appears that the extraction capacity for the boron, under the experimental conditions employed, is $9.73 \mathrm{mg} \mathrm{B} / \mathrm{g}$ resin.

Using the as-received ion exchange resin in the continuously fed seeded microfiltration cell, the concentration of the effluent from the cell (and concentration within the cell) as a function of time is plotted in Figure 3 for two inlet feed concentrations. The as-received resin had a surface area per unit volume equivalent spherical diameter (Sauter mean diameter) of 530 micrometers, which provided a mass transfer coefficient of $1.33 \times 10^{-4} \mathrm{~m} \mathrm{~s}^{-1}$ using equation 7 . It was not possible to independently deduce the boron diffusivity in the resin particle, so the two model curves illustrated in Figure 3 are best fit values for the diffusivity within the resin. However, once established from these experiments the boron diffusivity was not altered for the modelling of the remaining tests: the batch extractions and the 
experiments using crushed ion exchange resin. The apparent aqueous film thickness around the resin bead was calculated from equation 6 , for the two different bead sizes. All the inputs to the model, and the calculated variables from the modelling, are summarised in Table 4.

The experiments to test the validity of the modelling approach performed by crushing the ion exchange resin to a new Sauter mean diameter size: 190 micrometers, and repeating the continuously fed seeded microfiltration tests are shown in Figure 4. The boron concentration with respect to time in the cell, and permeate, are illustrated. The predicted curves are in reasonable agreement with the experimental data, with only a slight overestimate when predicting the extraction from a system fed at $2 \mathrm{ppm}$.

In the conventional kinetic modelling of a batch stirred systems with ion exchange resin present, the solute concentration reduces with respect to time. Such a plot is illustrated in Figure 5, for the two different ion exchange resin diameters. Figure 5 includes the model prediction for the kinetics, for both resin diameters, and the agreement is very good. For the calculations, the effective boron diffusivity within the resin particle was maintained at the value of $5.5 \times 10^{-10} \mathrm{~m} \mathrm{~s}^{-2}$ and the mass transfer coefficients were calculated from equation 7.

In Figure 6 the conventional plot of log normalised concentration against time is illustrated for the batch extraction data. In the simplified modelling approach (neglecting mass transfer resistance in the particle) this plot may be used to determine the mass transfer coefficient by taking the gradient at the start of the extraction. On the figure, the lines marked as the model are using the mass transfer coefficients given 
by equation 7 and neglecting internal resistance. Clearly, the experimental data deviates from a simple mass transfer model very quickly, within the first 40 seconds of the batch extraction. This can be explained by the very high resistance to mass transfer given by the low boron diffusivity within the resin bead. Hence, a significant concentration of boron builds up at the surface of the bead from an early stage.

For comparison, Figure 7 illustrates the initial stage of a boron extraction using the continuously fed seeded microfiltration system using $0.4 \mathrm{~g}$ of resin, $400 \mathrm{ml}$ solution and $4 \mathrm{ppm}$ of boron fed to the system. As the concentration in the aqueous phase starts at zero, and only slowly increases, a significant concentration of boron at the surface of the ion exchange resin bead does not occur until much later: about 180 seconds. Under these conditions, which are similar to those used in the batch extractions, the initial agreement between the simple model (mass transfer resistance in the aqueous film only) and the more realistic model (film and internal particle diffusion) is good up until 180 seconds. Whereas deviation between these models occurred at less than 40 seconds in the batch kinetic tests.

Hence, when investigating a simple mass transfer model, resistance due only to aqueous film, it is possible to use the seeded microfiltration cell to obtain samples over a much longer time period than can be when using the conventional approach of a batch stirred system. Thus, the continuously fed system is preferable to the batch one for simple mass transfer studies as well as coupled models between mass transfer and internal diffusion. 
One of the main reasons for the relatively poor modelling performance of the conventional approach (batch stirred tank using a relatively high boron concentration - see Figure 6) is the very low mass transfer of the boron within the resin. This implies that the resin is not being utilised very effectively as the outer shell of the particle will have a significant boron concentration, whilst towards the centre the resin bead will have a much lower boron concentration. This will limit the time that the resin can remain on-line whilst performing adequate boron extraction from the aqueous phase. One way to improve the resin utilisation is to decrease the resin size, so that the boron does not have to diffuse as far within the resin bead. However, smaller resin particles have higher pressure drops when used in packed bed devices, such as the extraction columns used for conventional ion exchange. Seeded microfiltration using resin beads does not suffer from this drawback, as the resin is not contained in a packed bed. It is used as a low concentration suspension $(<<1 \%$ $\mathrm{w} / \mathrm{w})$. The limit of particle size to the industrial use of seeded microfiltration is the smallest size that can be easily retained by a microfilter and a microfilter design that does not foul significantly by the resin, or by other material present in the feed suspension. This is not a trivial problem, but a recent development has provided a low fouling slotted microfilter system capable of retention of resin particles $<10$ micrometer without any internal surface on which colloidal material within the suspension could foul (Bromley et al, 2002).

From the above tests, the model incorporating boron diffusional resistance within the bead as well as across the aqueous film around the bead appears to provide an adequate representation of the boron mass transfer. An illustrative use of the model is to consider the time that the system could remain on-line for the purposes of 
providing permeate water below the WHO guideline for boron concentration in drinking water (300 ppb), as a function of particle size of the resin. At the large particle sizes the resin is poorly utilised as only the layers close to the surface take up a significant concentration of boron. At the very small sizes the resin is better utilised, but the diffusional gradient within the resin bead becomes less steep as boron can be transported towards the bead centre more easily. Thus, smaller bead sizes will always provide better overall performance, but the increase in the time taken for the permeate to remain below $300 \mathrm{ppb}$, with respect to a smaller particle size, will decrease at the very small bead sizes. Also, the practical problems of handling smaller beads will become significant. Thus, there appears to be a compromise bead size of about 50 to 60 micrometers, which should provide good service lifetime, but will easily be retained by the 8 micrometer slotted membrane used for the seeded microfiltration. This analysis illustrated in Figure 8 was based on $0.4 \mathrm{~g}$ of resin used in a $400 \mathrm{ml}$ cell, for all the different diameter resin beads tested. Clearly, it is possible to solve the model described by the set of equations given as equation 13 for higher feed rates, tank volumes, etc. to provide a scaled-up version of the boron extraction. However, given the slow rate of mass transfer within the bead a particle diameter of about 50 micrometers is a good compromise between enhancing the kinetics and not adversely influencing the microfiltration for all scales of operation during a seeded microfiltration process.

\section{CONCLUSIONS}

In conventional ion exchange resin beads are used in packed beds within columns and there is a requirement to ensure that the pressure drop within the column is low. Hence, bead sizes are usually large (greater than 100 micrometer diameter) and fine 
filtration is performed beforehand to ensure that solids do not deposit within the interstices of the resin particles. Both of these restrictions are removed with seeded microfiltration, provided the membrane is capable of retaining the ion exchange resin, but not fouling with whatever colloidal material is present. New slotted microfilters fulfil this requirement. In the case of boron mass transfer to one of the $\mathrm{N}$-glucamine type resins the mass transfer appears to be dominated by the effective diffusivity inside the particle. Hence, smaller particle sizes would be more appropriate and the modelling shows that an optimum particle diameter of about 50 micrometers would be best.

The mass transfer modelling of the seeded microfiltration, and conventional batch extraction, of boron on this resin showed that the Frössling equation was adequate in determining the aqueous film mass transfer coefficient independently of any experimental work, but that because of the slow mass transfer of boron inside the particle the process could not be described by aqueous film diffusion for very long. Hence, any analysis technique relying on this, such as determination of an empirical mass transfer coefficient, would be likely to lead to error. The seeded microfiltration cell helped, compared to conventional batch stirred tank for this laboratory study, as it was possible to start the experiment with a very low concentration of the transferring species within the aqueous phase - something that is not so easily performed with a conventional batch stirred tank test. However, the most appropriate method of determining the mass transfer parameters was to iteratively fit the required coefficient in the model and check to see the agreement between the model and experimental data. The coupled aqueous film and particle diffusion model was quickly solved with an off-the-shelf equation solver. The mass transfer coefficient over the aqueous film 
was, in fact, predicted to a good degree of precision by the Frössling equation. Thus, only the effective particle diffusion of boron needed determining experimentally. This parameter was then checked by altering experimental conditions in which it should remain constant, but the overall mass transfer change by varying: particle size, feed concentration and from continuous to batch extraction tests. The modelling approach was tested by comparison between the experimental data and the model. The agreement appeared to be very good.

The seeded microfiltration cell is a useful technique for laboratory investigation of mass transfer parameters and can provide appropriate scale-up data for process-scale operation of a seeded microfiltration process in which a solute could be recovered by a continuous microfiltration process, such as crossflow filtration. Using the cell it is possible to measure the hydraulic resistance of the membrane, effect of colloidal species and the specific permeate flux rate - providing all the necessary data for a design of the process-scale equipment as well as the mass transfer parameters and modelling.

\section{LIST OF SYMBOLS}

A surface area of the resin bead, $\quad \mathrm{m}^{2}$

$b \quad$ Langmuir isotherm model parameter, $\quad \mathrm{ppm}^{-1}$

C concentration in the solution (both in cell and at the exit), ppm

$C_{\mathrm{eq}} \quad$ equilibrium boron concentration in the liquid phase, ppm

$C_{\text {feed }}$ concentration in the feed to the cell, $\quad \mathrm{ppm}$

$C^{*}$ equilibrium boron concentration at the surface of the resin, $\quad \mathrm{ppm}$

$D_{\text {eff }} \quad$ effective diffusion coefficient of boron inside the particle, $\quad \mathrm{m}^{2} \mathrm{~s}^{-1}$ 
$D_{\text {liq }} \quad$ diffusion coefficient of the boron in the bulk liquid phase, $\quad \mathrm{m}^{2} \mathrm{~s}^{-1}$

$F \quad$ feed flow rate, $\quad \mathrm{m}^{3} \mathrm{~s}^{-1}$

$k$ mass transfer coefficient in the liquid phase, $\mathrm{m} \mathrm{s}^{-1}$

$m \quad$ mass of resin in the cell, $\quad \mathrm{kg}$

$q \quad$ boron concentration on the resin particles, $\quad \mathrm{g} \mathrm{g}^{-1}$

$\bar{q} \quad$ average mass of boron per mass of resin, $\quad \mathrm{g} \mathrm{g}^{-1}$

$q_{\max } \quad$ maximum capacity of the resin particle, $\quad \mathrm{g} \mathrm{g}^{-1}$

$R \quad$ bead radius, $\quad \mathrm{m}$

$r \quad$ radial position inside the particle, $\quad \mathrm{m}$

$t$ time, $\quad \mathrm{s}$

$V \quad$ liquid volume in the cell, $\quad \mathrm{m}^{3}$

$V_{\text {resin }} \quad$ resin particle volume, $\quad \mathrm{m}^{3}$

$x \quad$ diameter of the resin particle, $\quad \mathrm{m}$

Greek

$\delta \quad$ film thickness, $\quad \mathrm{m}$

$\mu \quad$ liquid viscosity, $\quad \mathrm{kg} \mathrm{m}^{-1} \mathrm{~s}^{-1}$

$\rho \quad$ liquid density, $\quad \mathrm{kg} \mathrm{m}^{-3}$

$\rho_{s} \quad$ density of the particle, $\quad \mathrm{kg} \mathrm{m}^{-3}$

\section{REFERENCES}

Badruk, M., Kabay, N., Demircioglu, M., Mordogan, H. and Ipekoglu, U., 1999a, Removal of boron from wastewater of geothermal power plant by selective ionexchange resins I: batch sorption-elution studies, Sep. Sci. Technol., 34(13), 25532569. 
Badruk, M., Kabay, N., Demircioglu, M., Mordogan, H. and Ipekoglu, U., 1999b, Removal of boron from wastewater of geothermal power plant by selective ionexchange resins II: column sorption-elution studies, Sep. Sci. Technol., 34(13), 29812995.

Boncukcuoğlu, R., Yllmaz, A.E., Kocakerim, M.M. and Çopur, M., 2004, An empirical model for kinetics of boron removal from boron-containing wastewaters by ion exchange in a batch reactor, Desalination, (160): 159-166.

Bromley, A.J., Holdich, R.G. and Cumming, I.W., 2002, Particulate fouling of surface microfilters with slotted and circular pore geometry, Jnl. Mem. Sci., 196: 27-37.

Cumming, I.W., and Turner, A.D., 1989, Future industrial prospects of membrane processes, Ed. Cecille, L. and Toussaint, J.C., Elsevier, Amsterdam, pp 76-96.

Dilek, Ç., Özbelge, H.Ö., Biçak, N. and Yllmaz, L., 2002, Removal of boron from aqueous solutions by continuous polymer enhanced unltrafiltration with polyvinyl alcohol, Sep. Sci. Technol., 37(6), 1257-1271.

Holdich, R.G., 2002, Fundamentals of Particle Technology, MidlandIT Publishing, Shepshed, UK.

Kabay, N., Yilmaz, I., Yamac, S., Samatya, S., Yuksel, M., Yuksel, U., Arda, M., Saglam, M., Iwanaga, T., Hirowatari, K., 2004, Removal and recovery of boron from geothermal wastewater by selective ion exchange resins. I. Laboratory tests, React. Funct. Polym., 60: 163-170.

Lou, J.D., Foutch, G.L. and Na, J.W., 1999, The sorption capacity of boron on anionic-exchange resin, Sep. Sci. Technol., 34(15): 2923-2941.

Nadav, N., 1999, Boron removal from seawater reverse osmosis permeate utilizing selective ion exchange resin, Desalination, (124): 131-135. 
Qi, T., Sonoda, A., Makita, Y., Kanoh, H., Ooi, K. and Hirotsu, T., 2002, Synthesis and borate uptake of two novel chelating resins, Ind. Eng. Chem. Res., 42: 133-138. Ristić, M. and Rajaković, V., 1996, Boron removal by Anion Exchangers impregnated with citric and tartaric acid”, Sep. Sci. Technol., 31(20), 2805-2914. Şahin, S., 2002, A mathematical relationship for the explanation of ion exchange for boron adsorption, Desalination 143: 35-43.

Simonnot, M., Castel, C., Nicolai, M., Rosin, C., Sardin, M. and Jauffret, H., 2000, Boron Removal from Drinking Water with a Boron Selective Resin: Is the Treatment Really Selective. Wat. Res., 34(1): 109-116.

WHO, 1998, Guidelines for drinking water quality - Boron, 2nd. Ed., Geneva, World Health Organisation (WHO), pp. 4-6.

Yiacoumi, S. and Tien, C., 1995, Kinetics of metal ion adsorption from aqueous solutions: models, algorithms and applications, Kluwer, Boston, USA. 
Table 1 Capacity of various commercial anion exchange resins for boron and some boron chelating resins

\begin{tabular}{|l|c|}
\hline \multicolumn{1}{|c|}{ Resin } & Capacity (mg B/g resin) \\
\hline \hline IRA 93 & 0.39 \\
IRA 93 + citric acid & 0.55 \\
IRA 93 + tartaric acid & 0.55 \\
IRA 400 & 0.60 \\
IRA 400 + citric acid & 1.19 \\
IRA 400 + tartaric acid & 0.98 \\
WOFATIT L150 & 1.69 \\
WOFATIT + citric acid & 2.60 \\
WOFATIT + tartaric acid & 2.12 \\
Purolite S-108 & 9.7 \\
Diaion CRB02 & 10 \\
\hline
\end{tabular}


Table 2 Characteristics of the as-received Purolite S-108 ion exchange resin

\begin{tabular}{|l|l|}
\hline Polymer matrix structure & Macroporous styrene-divinylbenzene \\
Physical form and appearance & Opaque cream spheres \\
Functional groups & Complex amino \\
Whole bead count & $>95 \%$ \\
Ionic form (as shipped) & $\mathrm{Cl}^{-}$ \\
Shipping density g/dm & \\
Screen size range British standard screen & 650 \\
Moisture retention $\mathrm{Cl}^{-}$form & $16-52$ mesh \\
Specific gravity, moist $\mathrm{Cl}^{-}$form & $52-58 \%$ \\
Maximum operating temperature & 1.06 (value rounded to 1.1) \\
Operating $\mathrm{pH}$ & $60{ }^{\circ} \mathrm{C}$ \\
Specific surface area $\mathrm{m}^{2} / \mathrm{g}$ & $1-13$ \\
\hline
\end{tabular}


Table 3 Particle size distributions of ion exchange resin

\begin{tabular}{|c|c|c|}
\hline $\begin{array}{c}\text { Amount by mass less } \\
\text { than corresponding } \\
\text { particle size } \\
(\%)\end{array}$ & $\begin{array}{c}\text { As-received } \\
\text { Purolite S-108 } \\
\text { resin } \\
(\mu \mathrm{m})\end{array}$ & $\begin{array}{c}\text { Crushed Purolite } \\
\text { S-108 resin }\end{array}$ \\
\hline 0 & 350 & 90 \\
\hline 10 & 430 & 115 \\
\hline 30 & 510 & 160 \\
\hline 50 & 550 & 210 \\
\hline 70 & 590 & 260 \\
\hline 90 & 660 & 370 \\
\hline 100 & 750 & 550 \\
\hline
\end{tabular}


Table 4 Summary table of conditions used in tests and modelling

\begin{tabular}{|c|c|c|}
\hline Parameter & Value & Units \\
\hline Liquid volume in the cell & 400 & $\mathrm{ml}$ \\
\hline Diameter of membrane used in cell & 80 & $\mathrm{~mm}$ \\
\hline Mass of ion exchange resin inside cell & 0.4 & g \\
\hline Sauter diameter of ion exchange resin bead - I & 530 & $\mu \mathrm{m}$ \\
\hline Sauter diameter of ion exchange resin bead - II & 190 & $\mu \mathrm{m}$ \\
\hline Liquid viscosity & 0.001 & Pa s \\
\hline Liquid density & 1000 & $\mathrm{~kg} \mathrm{~m}^{-3}$ \\
\hline Resin bead density (when swollen) & 1100 & $\mathrm{~kg} \mathrm{~m}^{-3}$ \\
\hline Boron diffusivity in water & $8 \times 10^{-5}$ & $\mathrm{~cm}^{2} \mathrm{~s}^{-1}$ \\
\hline Boron diffusivity in resin & $5.5 \times 10^{-10}$ & $\mathrm{~cm}^{2} \mathrm{~s}^{-1}$ \\
\hline Initial boron concentration inside the fed cell & 0 & ppm \\
\hline Boron concentration in feed to cell & 1 to 4 & ppm \\
\hline Feed flow rate to (and permeate rate from) cell & 42 to 72 & $\mathrm{ml} \mathrm{min}^{-1}$ \\
\hline \multicolumn{3}{|l|}{ Calculated values during solution: } \\
\hline Terminal velocity $530 \mu \mathrm{m}$ bead (not by Stokes') & 0.0101 & $\mathrm{~m} \mathrm{~s}^{-1}$ \\
\hline Terminal velocity $190 \mu \mathrm{m}$ bead (not by Stokes') & 0.0019 & $\mathrm{~m} \mathrm{~s}^{-1}$ \\
\hline Mass transfer coefficient $530 \mu \mathrm{m}$ beads & $1.33 \times 10^{-4}$ & $\mathrm{~m} \mathrm{~s}^{-1}$ \\
\hline Mass transfer coefficient $190 \mu \mathrm{m}$ beads & $1.59 \times 10^{-4}$ & $\mathrm{~m} \mathrm{~s}^{-1}$ \\
\hline $\begin{array}{l}\text { Apparent aqueous film thickness around resin bead, } \\
530 \mu \mathrm{m}\end{array}$ & 60 & $\mu \mathrm{m}$ \\
\hline $\begin{array}{l}\text { Apparent aqueous film thickness around resin bead, } \\
190 \mu \mathrm{m}\end{array}$ & 50 & $\mu \mathrm{m}$ \\
\hline
\end{tabular}


List of Tables

Table 1 Capacity of various commercial anion exchange resins for boron and some boron chelating resins

Table 2 Characteristics of the as-received Purolite S-108 ion exchange resin

Table 3 Particle size distributions of ion exchange resin

Table $4 \quad$ Summary table of conditions used in tests and modelling

List of Figures

Figure $1 \quad$ Schematic diagram of seeded microfiltration cell

Figure 2 Langmuir isotherm for boron on Purolite S-108

Figure 3 Continuous feed of boron solution to the seeded microfiltration cell boron concentration in the effluent with time using 530 micrometer resin beads

Figure 4 Continuous feed of boron solution to the seeded microfiltration cell boron concentration in the effluent with time using 190 micrometer resin beads

Figure 5 Extraction of boron during batch cell tests using two different resin bead diameters: 530 and 190 micrometers

Figure $6 \quad$ Conventional approach to mass transfer modelling during batch extraction: the log-linear plot with initial boron concentration of 4 ppm

Figure 7 Comparison of boron concentration in aqueous phase at the start of the seeded microfiltration based on no internal mass transfer resistance inside resin bead and with resistance for a 530 micrometer diameter particle -4 ppm boron feed

Figure 8 Time taken for effluent to reach $300 \mathrm{ppb}$ during seeded microfiltration starting with $0 \mathrm{ppm}$ boron in filtration cell for different resin diameters 